\title{
EVALUATION METHODS FOR SMART SENSORS PERFORMANCES INTEGRATED IN TCP/IP INFRASTRUCTURE
}

\author{
Risteiu, M.; Ileana, I.; TUlbure, A. \& CROITORU, B.
}

Abstract: Paper shows an approach of evaluating Zigbee sensors integrated into $802.11 \mathrm{~g}$ networks for wireless remote control. The evaluating criteria is roundtrip time delay, modeled, simulated and measured in laboratory setup. For the quality of wireless connection, some in site measurements has been done. Some time delay limits has been established, correlated with different types of smart sensors. By integrating smart sensors with wireless TCP/IP devices, total delay limits also has been measured and evaluated. TinyOS software has been implemented. For some slow process control implementations, the main delay is happening because of smart sensors implementation. The optimal tuning for a random delay with a small variance have to be next experimented for some particular cases. For instance, in implementations like non-beaconing integration with TCP/IP network, we must deeply analyze also stability of $802.11 \mathrm{~g}$ wireless connection.

Key words: Remote process control, Zigbee sensors, 802.15.4 radio communication, delay, network modeling, radio measurements, power optimization, TinyOS
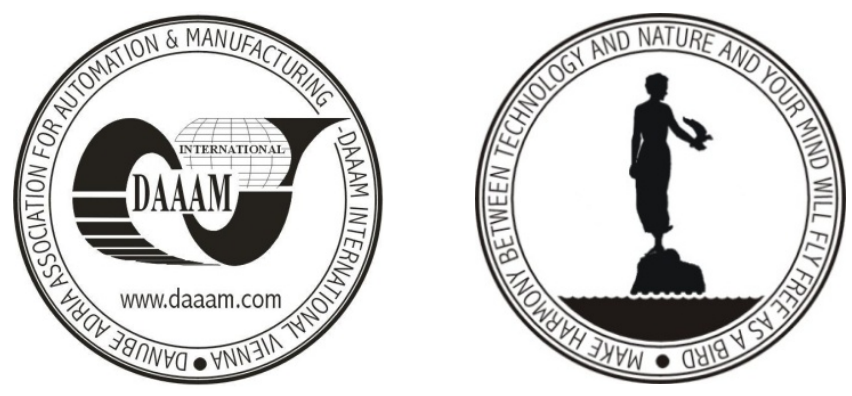

Authors' data: Prof. Risteiu, M[ircea]; Ileana, I[oan]; Prof. Tulbure, A[drian]; Croitoru, B[ogdan], University of Alba iulia, N.Iorga Str. No.11, 510009, Alba Iulia, RO, aditulbure@uab.ro,csbn_alba@yahoo.com, iileana@uab.ro,mristeiu@uab.ro

This Publication has to be referred as: Risteiu, M[ircea]; Ileana, I[oan]; Tulbure, A[drian] \& Croitoru, B[ogdan] (2008). Evaluation Methods for Smart Sensors Performances Integrated in TCP/IP Infrastructure, Chapter 55 in DAAAM International Scientific Book 2008, pp. 641-656, B. Katalinic (Ed.), Published by DAAAM International, ISBN 978-3-901509-66-7, ISSN 1726-9687, Vienna, Austria DOI: $10.2507 /$ daaam.scibook.2008.55 